\title{
Postoperative Tomographic Assessment of Veneer Bone Grafting with Implant Placement in the Maxillary Anterior Region
}

\author{
Munetaka Naitoh, DDS, PhD, ${ }^{\star}$ Karl Dula, DDS, PhD, $†$ Yasuhiro Ito, DDS, PhD, $\ddagger$ Tetsuro Toyoda, DDS, PhD, $\S$ \\ Kenichi Kurita, DDS, PhD,\| and Eiichiro Ariji, DDS, PhD\|
}

$\mathrm{R}$ ecently, various augmentation procedures (e.g., onlay bone grafting and the maxillary sinus lift procedure) were performed for severely resorbed residual ridges and alveolar crests close to the maxillary sinus floor for implant treatment. ${ }^{1-5} \mathrm{~A}$ critical review of the findings showed variations in the implant survival rates. ${ }^{4,6-8}$ Lekholm et $a l^{4}$ reported a 3-year retrospective study of bone grafting with implant placement that showed an overall implant survival rate of approximately $80 \%$. Keller et $a l^{6}$ showed that the survival rate for endosseous implants with maxillary antral-nasal inlay autogenous bone grafting was $87 \%$. Widmark et $a l^{7}$ reported that a life table analysis showed a cumulative success rate of $74 \%$ in the graft group and $87 \%$ in the trial group at the final examination after $3-5$ years. These results corroborated previous findings that patients with severely resorbed maxillae have an in-

*Associate Professor, Department of Oral and Maxillofacial Radiology, School of Dentistry, Aichi-Gakuin University, Nagoya, Japan; Oral Implant Clinic, Dental Hospital, AichiGakuin University, Nagoya, Japan; Visiting Research Professor, Section of Dentomaxillofacial Radiology, Department of Oral Surgery and Stomatology, School of Dental Medicine, University of Berne, Berne, Switzerland. †Associate Professor, Section of Dentomaxillofacial Radiology, Department of Oral Surgery and Stomatology, School of Dental Medicine, University of Berne, Berne, Switzerland. tPart-time Assistant Professor, First Department of Oral and Maxillofacial Surgery, School of Dentistry, Aichi-Gakuin University, Nagoya, Japan. §Assistant Professor, Department of Health Science, Faculty of Psychological and Physica

University, Nagoya, Japan. Maxillofacial Surgery Schol of Maxiloricial Surgery, School of Dentistry, Aichi-Gaku University, Nagoya, Japan.

IProfessor and Chairman, Department of Oral and

gy, School of Dentistry, Aichi-Gakuin

ISSN 1056-6163/05/01403-301

Implant Dentistry

Volume 14 - Number 3

Copyright (C) 2005 by Lippincott Williams \& Wilkins

DOI: 10.1097/01.id.0000174903.85738.c3
Various ridge augmentation and sinus lift procedures were performed in severely resorbed alveolar crests of a maxilla to provide some volume for implant treatment. It was reported that the outcome of maxillary sinus lift procedures was evaluated with conventional tomography or computerized tomography, and that grafted bone around implants markedly progressed in resorption, particularly at the implant apex. However, veneer bone grafting with implant placement has not been evaluated after treatment with imaging techniques. Therefore, the purpose of this study was to assess veneer bone grafting after maxillary anterior implant treatment. Seven patients with a mean age of 24 years, with implants placed in the maxillary anterior region with or without autogenous veneer bone grafting were postoperatively examined using con-

creased risk of implant failure in comparison to those with good bone quantity and quality. Moreover, maxillary sinus lift procedures were evaluated using computerized tomography (CT). It was found that grafted bone surrounding the implants severely progressed in resorption, particularly at the implant apex..$^{9-11}$ However, veneer bone grafting with implant treatment has not been evaluated using postoperative imaging. Therefore, veneer bone grafting after maxillary anterior implant treatment was assessed and ventional tomography. On tomograms, the ratio of bone-to-implant contact and the area of bone were measured in labial bones with bone grafts, and they were compared with the values without bone grafts. In cases with bone grafting, the average ratio of bone-to-implant contact was $63.6 \%$, whereas $81.8 \%$ was formed in cases without bone grafting. The average area of bone was $12.9 \mathrm{~mm}^{2}$ and $23.4 \mathrm{~mm}^{2}$ in patients with and without bone grafting, respectively. No significant difference was found between the implants with and without bone grafts. Resorbed labial bone was observed in the maxillary anterior region with and without veneer bone grafting. (Implant Dent 2005;14:301-307)

Key Words: dental implant, veneer bone graft, maxillary anterior region, tomography, postoperative findings

compared with the findings without bone grafting.

\section{Materials and Methods}

In 7 patients (4 males and 3 females) with a mean age of 24 years (range 15-40), implants were placed in the maxillary anterior region with or without autogenous veneer bone grafting and postoperatively examined using conventional tomography. All treatments, bone grafts, implant placements, and tomography were performed in the Dental Hospital 


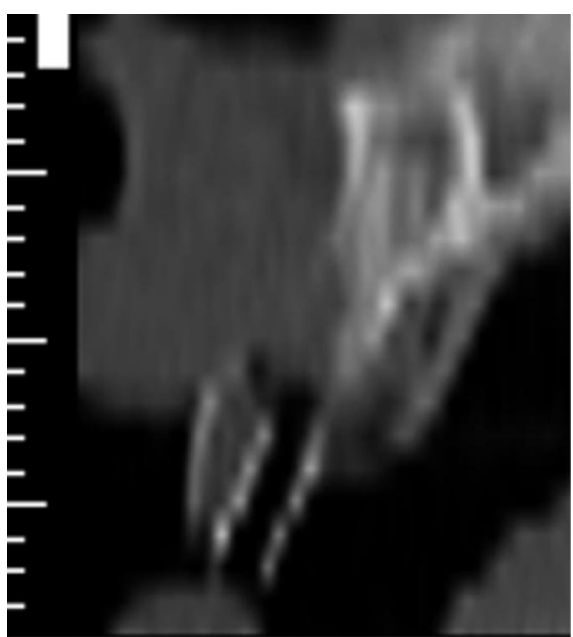

Fig. 1. CT before bone grafting. A narrow alveolar bone in the buccolingual plane of the maxillary anterior region is shown.

of Aichi-Gakuin University. Tooth loss was caused by traumatic injury in 5 of the 7 patients, congenitally missing in 1 , and periodontal disease in 1 .

\section{Bone Grafts and Implant Placements}

Autogenous veneer bone grafts were performed at the site of the planned implant, diagnosed as narrow alveolar bone width using preoperative imaging, a few months before implant placement (Fig. 1). During the presurgical imaging diagnosis, when a thickness of labial bone over a planned implant is $<1 \mathrm{~mm}$ along a planned implant, bone grafts were scheduled. In addition, the thickness of bone graft was $>1 \mathrm{~mm}$, except in cases of an expected resorbed thickness $(1 \mathrm{~mm})$ along a labial side of a planned implant. In all cases, the bone grafts used were corticocancellous bone blocks harvested from the chin. The cancellous bone surface of the bone blocks was placed on labial maxillary cortical bone with a screw(s) (Fig. 2). The bone surface was then covered by a healthy periosteum.

Implant placement was performed in accordance with surgery methods reported by Naitoh et al. ${ }^{12}$ Nine implants with bone grafting ( 7 in the central incisor region, 1 in the lateral incisor region, and 1 in the canine region) and 4 implants without bone grafting (all at the central incisor region) were placed. All implants were from the Brånemark System implant (Nobel Biocare, Göteborg, Sweden).

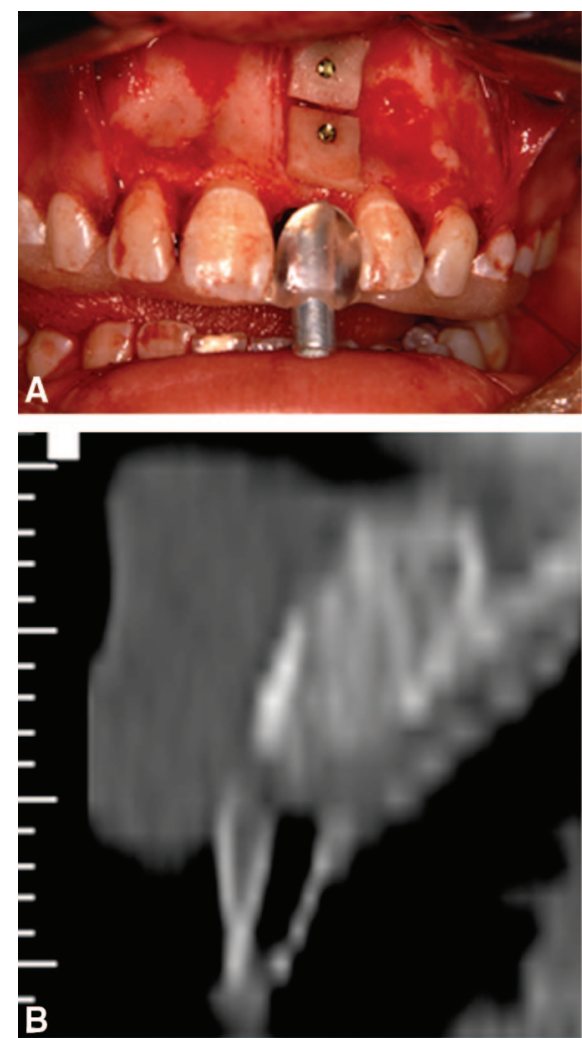

Fig. 2. A, Autogenous veneer bone graft was performed at the site of the planned implant site diagnosed as a narrow alveolar bone width. B, CT after bone grafting.

No perforation of the implant on the labial or palatal side of the nasal floor was observed during implant placement. Bone blocks of bone grafting were fixed tightly to maxillary bone. The time between bone grafting and implant placement, and between implant placement and abutment connection is shown in Table 1.

\section{Tomographic Imaging}

Cross-sectional linear tomography was performed after some months of abutment connection using a panoramic unit (AZ3000DLP, Asahi

Table 1. Duration of Implant Treatments

\begin{tabular}{lcc}
\hline & $\begin{array}{c}\text { With Bone } \\
\text { Grafting }\end{array}$ & $\begin{array}{c}\text { Without Bone } \\
\text { Grafting }\end{array}$ \\
\hline $\begin{array}{c}\text { Mean time between bone graft } \\
\text { and implant placement (range) }\end{array}$ & $79.0(59-101)$ & \\
$\begin{array}{l}\text { Mean time between implant } \\
\text { placement and abutment }\end{array}$ & $198.8(149-310)$ & $267.5(166-330)$ \\
$\quad$ connection (range) & & \\
$\begin{array}{l}\text { Mean time between implant } \\
\text { placement and tomography } \\
\text { (range) }\end{array}$ & $343.7(269-425)$ & $794.5(316-1255)$ \\
\hline Units are in days. & & \\
\hline
\end{tabular}

Roentgen Ind. Co., Kyoto, Japan). Mean time between the implant placement and tomography was 343.7 days for implants with bone grafting and 794.5 days without bone grafting (Table 1). The exposure settings were selected for $68 \mathrm{kVp}$ and $6 \mathrm{~mA}$, with a 40-degree tomographic projection angle. Obtained tomograms were printed on film at absolute size using a CR system (FCR9000 HQ, HI-654, CRLPD, Fuji Medical System Co, Tokyo, Japan). The films were converted to digital images using a film digitizer with 150 dpi (VXR-12 plus, Vidar Systems Co., Herndan, VA) (Figs. 3 and 4) and were measured using image editing software (Photoshop version 5.5, Adobe Systems Inc., San Jose, $\mathrm{CA})$. First, the $\mathrm{x}$ and $\mathrm{y}$ coordinates of the superior and inferior points of the implants covered by labial bone were recorded. The superior point $\left(\mathrm{X}_{2}, \mathrm{Y}_{2}\right)$ was regarded as a labial apex of implant, and the inferior point $\left(\mathrm{X}_{1}, \mathrm{Y}_{1}\right)$ was regarded as a crest of alveolar bone attached to implant (Fig. 5). The ratio of bone-to-implant contact was obtained using the following equation.

The length of implant covered by labial bone was calculated by

$$
\sqrt{\left(\mathrm{X}_{2}-\mathrm{X}_{1}\right)^{2}+\left(\mathrm{Y}_{2}-\mathrm{Y}_{1}\right)^{2}} \times \text { pixel size. }
$$

The ratio of bone-to-implant contact was calculated by the length of implant covered by labial bone/the real length of the implant.

Second, regions of interest were visually set at whole bone on the labial side of the implant, and the number of pixels in the area of regions of interest was quantitated. The area of bone was calculated by the number of bone pixels $\times$ pixel square. A surface of the implant was let a straight lined threads of implant, although a shape of the implant was screw. Postoperative 

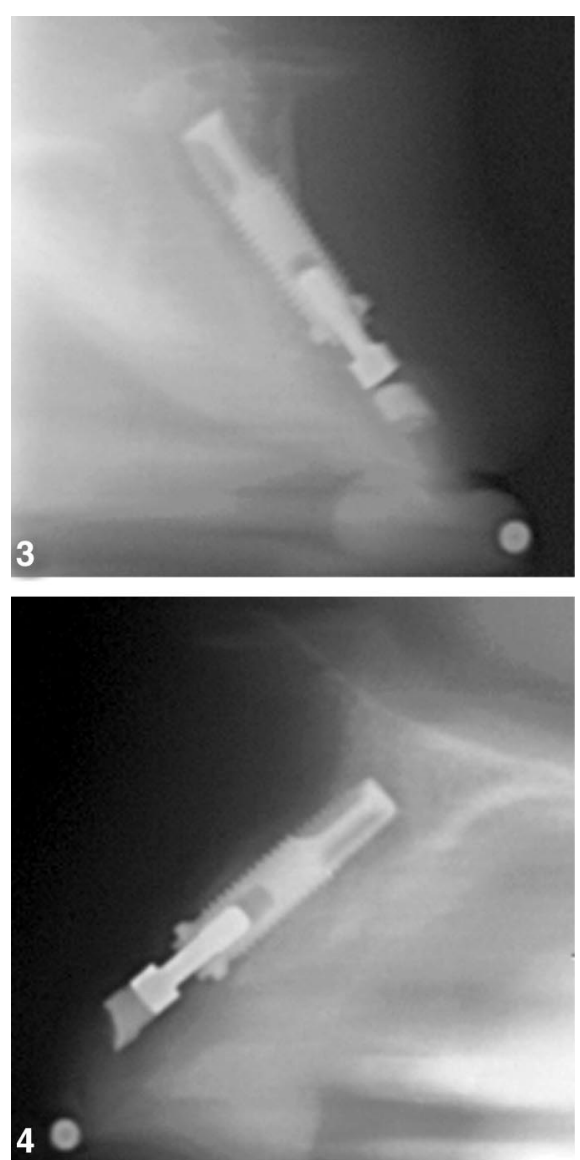

Fig. 3. Tomographic image of implant site with bone grafting. The resorbed labial bone of the implant is shown.

Fig. 4. Tomographic image of implant site without bone grafting. The labial bone of the implant is shown from the neck of the implant to the apex.

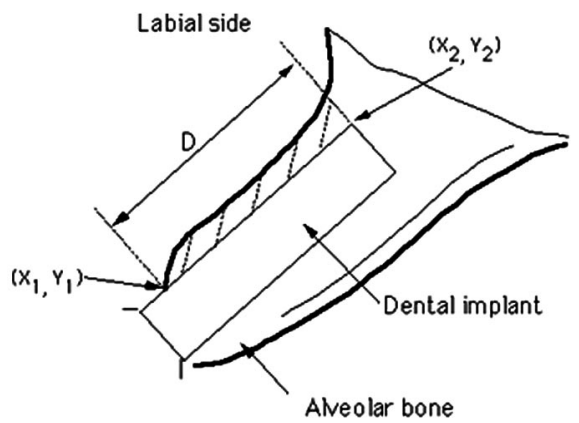

$(\square-C$ area: A )

Fig. 5. Schematic drawing of tomographic measurements. The length of implant covered by labial bone (D) and the number of labial bone pixels $(A)$ were measured.

labial bone with bone grafts was assessed from the ratio of bone-toimplant contact and the area of bone. The values were compared with values

Table 2. Tomographic Measurements

\begin{tabular}{lcc}
\hline & With Bone Grafting & Without Bone Grafting \\
\hline Ratio of bone contact $(\%)$ & $25.2-94.4$ & $53.9-93.4$ \\
Range & 63.6 & 81.8 \\
Mean & 24.0 & 18.8 \\
SD & & \\
Area of bone $\left(\mathrm{mm}^{2}\right)$ & $1.1-28.6$ & $11.3-47.7$ \\
Range & 12.9 & 23.4 \\
Mean & 10.0 & 17.2 \\
SD & & \\
\hline
\end{tabular}

$P<0.01$.

from sites without bone grafts calculated in the same way.

\section{Statistical Analysis}

The difference between the obtained values with and without bone graft was evaluated using the MannWhitney $U$ test. Testing was considered significant if $P<0.01$.

\section{RESUltS}

Results from sites with bone graft are shown in Table 2. The ratio of bone-to-implant contact ranged from $25.2 \%$ to $94.4 \%$, and the average was $63.6 \%$ (standard deviation [SD] 24.0). The area of bone ranged between 1.1 and $28.6 \mathrm{~mm}^{2}$, and the average was $12.9 \mathrm{~mm}^{2}$ (SD 10.0). The results from sites without bone graft are also shown in Table 2. The ratio of bone-toimplant contact ranged from $53.9 \%$ to $93.4 \%$, and the average was $81.8 \%$ (SD 18.8). The area of bone ranged between 11.3 and $47.7 \mathrm{~mm}^{2}$, and the average was $23.4 \mathrm{~mm}^{2}$ (SD 17.2).

\section{Comparison Between Values With and Without Bone Grafts}

No significant difference in the ratio of bone-to-implant contact and the area of bone was found between the implant with and without bone grafts $(P=0.16$ for the ratio of boneto-implant contact and $P=0.35$ for the area of bone). No correlation between the period between the implant placement and tomography, and the ratio of bone-to-implant contact or the area of bone was clearly found in cases with bone graft and without bone graft (Figs. 6 and 7).

\section{Discussion}

Various bone grafting methods and implantation times have been reported. ${ }^{1,3-6,11,13,14}$ In the present study, autogenous corticocancellous bone grafts were harvested from the chin and placed as veneer bone blocks on the labial side of the alveolar process of the maxilla. Because the bone surface was covered by a healthy periosteum with release incision, no membrane technique was used in all cases. Widmark et $a l^{15}$ reported that bone resorption in the buccal/palatal direction of the anterior maxilla was $25 \%$ after 4 months of bone graft and $60 \%$ after 10
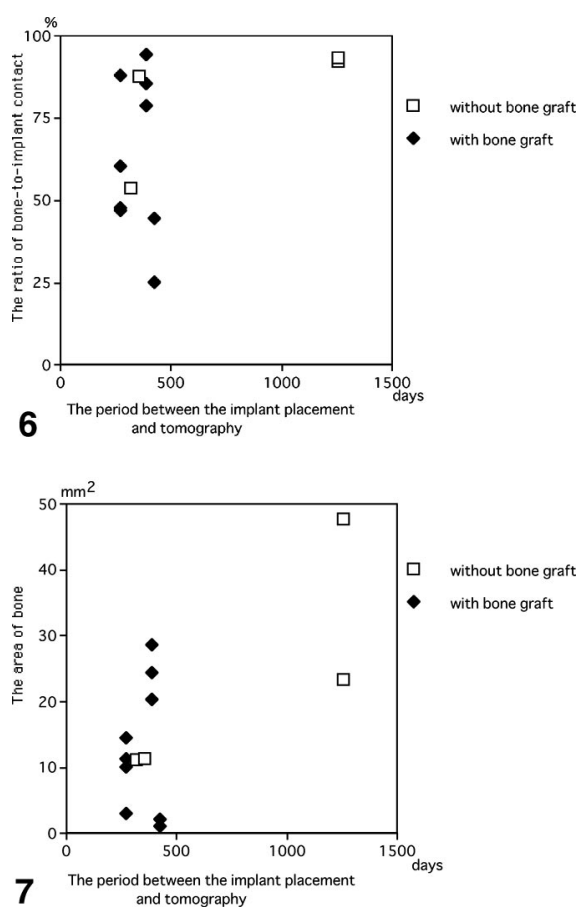

Fig. 6. Correlation between the period and the ratio of bone-to-implant contact. No correlation between the period between the implant placement and tomography, and the ratio of bone-to-implant contact was found in cases with bone graft and without bone graft. Fig. 7. The correlation between the period and the area of bone. No correlation between the period between the implant placement and tomography, and the area of bone was found in cases with bone graft and without bone graft. 
months following bone graft, when a bone graft from the symphyseal region of the mandible was used in the maxillary central incisor region.

For postoperative evaluations of maxillary sinus lift procedures, tomography or CT have been used as imaging techniques. However, after placed dental implant, CT images have a metal artifact from dental implant made of titanium, and correct diagnosis in implant-to-bone interface was not performed. In addition, CT has the partial volume effect showing less points. ${ }^{16}$ Tomograms with a direct laser positioning system were used in the present study to observe the labial side of implants. ${ }^{17}$ The position of the tomographic plane was set on the basis of the occlusal surface impression, and direction of the tomographic plane was set on the basis of the preoperative CT. Because the dental arch was a curve in the anterior region and the direction of x-rays in the tomography was set tangential to the anterior region, the tomograms showed clearly the bone in the labial side of implant without obstructive shadows on the anterior site. The implant threads could be clearly identified on all tomographic images obtained in this study.

This investigation was conducted as a retrospective study. Because the period between implant placement and tomography was more than 3 years for 2 implant sites without bone graft, mean time between the implant placement and tomography was different in cases with bone graft and without bone graft. However, no correlation between the period between the implant placement and tomography, and the ratio of bone-to-implant contact or the area of bone was clearly found in cases with bone graft and without bone graft.

It was observed that the ratio of bone-to-implant contact was low, and the area of bone was small in many cases with and without bone grafting. We consider the results of the ratio of bone-to-implant contact were more important. These results will influence directly a prognosis of dental implant treatment. In addition, in cases with bone graft, the value in the area of bone will be affected by the volume of bone graft. In the ratio of bone-toimplant contact, mean value with the bone graft was slightly lower than that without bone grafting, and the SD with bone grafting was slightly higher. All implants were clinically stable without complaint or mobility at tomography. The bone surrounding the implants that were placed with bone augmentation procedures and the bone in maxillary sinus lift procedures have been evaluated using postoperative imaging in some previous studies. Peleg et $a l^{10}$ reported radiologic findings in short-time (8-10 months) CT in a follow-up study for 1-stage maxillary sinus lift procedures. Of the 57 implants placed, 28 had a full bone covering the implants on all sides but did not extend above the apical portion, 20 had bone fully covering the implant, which extended above the apex, and 9 showed incomplete bone coverage.

Block et $a l^{9}$ measured the bone level using tomograms at 5-10 years after simultaneous maxillary sinus graft and implant placement, and the average height of the grafted bone at the implant apex was $3.3 \mathrm{~mm}$ (SD 3.1 $\mathrm{mm})$. Nystrom et $a l^{18}$ followed up 20 patients with combined horseshoeshaped iliac bone grafts and Brånemark implants in severely resorbed maxillae. In the results, the mean width of the bone graft was $12.2 \mathrm{~mm}$, which was significantly different from baseline $(P<0.001)$. It was reported that most of the bone width was lost during the first 3 months.

Resorption of bone was observed in the maxillary anterior region with and without veneer bone grafting using tomograms. It can be suggested that similar conditions may occur in cases with thin cortical bone. Even if bone of the labial site appears unclear on tomograms, the labial surroundings of the implant would be covered by thinner bone clinically. In addition, it was suggested that this resorption of bone was influenced by bone quality and tension of the lip. Further studies should evaluate the values in many cases with/without bone graft using no/some membrane techniques, and aim to discover the relationship between the measured bone volume and a prognosis that may be detected from the values.

\section{Conclusions}

The postoperative findings of veneer bone grafting in maxillary anterior implant treatment were assessed using tomography, and they were compared to the findings without bone grafting. It was clarified that the ratio of bone-to-implant contact was low and the area of bone was small in the maxillary anterior implants with and without bone grafts. The findings of resorbed bone grafts found at the implant apex with the maxillary sinus procedures were also observed on the labial side of the maxillary anterior region with and without veneer bone grafts.

\section{Disclosure}

The authors claim to have no financial interest in any company or any of the products mentioned in this article.

\section{ACKNowledgments}

The authors thank Dr. A. Katsumata from the Asahi University for his advice regarding the digital processing of tomograms.

\section{REFERENCES}

1. Jensen J, Sindet-Pedersen S. Autogenous mandibular bone grafts and osseointegrated implants for reconstruction of the severely atrophied maxilla: A preliminary report. J Oral Maxillofac Surg. 1991; 49:1277-1287.

2. Collins TA, Nunn W. Autogenous veneer grafting for improved esthetics with dental implants. Compend Contin Educ Dent. 1994;15:370,372-374.

3. Triplett GR, Schow SR. Autologous bone grafts and endosseous implants: Completely techniques. J Oral Maxillofac Surg. 1996;54:486-494

4. Lekholm U, Wannfors K, Isaksson S, et al. Oral implants in combination with bone grafts. A 3-year retrospective multicenter study using the Brånemark implant system. Int J Oral Maxillofac Surg. 1999; 28:181-187.

5. Buser D, Dula K, Hess D, et al. Localized ridge augmentation with autografts and barrier membranes. Periodontol 2000. 1999;19:151-163.

6. Keller EE, Tolman DE, Eckert SE. Maxillary antral-nasal inlay autogenous bone graft reconstruction of compromised maxilla: A 12-year retrospective study. Int J Oral Maxillofac Implants. 1999;14:707-721.

7. Widmark G, Andersson B, Carlsson $\mathrm{GE}$, et al. Rehabilitation of patients with severely resorbed maxillae by means of implants with or without bone grafts: A 3-5 
year follow-up clinical reports. Int J Oral Maxillofac Implants. 2001;16:73-79.

8. Raghoebar GM, Timmenga NM, Reinstema $\mathrm{H}$, et al. Maxillary bone grafting for insertion of endosseous implants: Results after 12-124 months. Clin Oral Implants Res. 2001;12:279-286.

9. Block MS, Kent JN, Kallukaran FU, et al. Bone maintenance 5 to 10 years after sinus grafting. J Oral Maxillofac Surg. 1998;56:706-714.

10. Peleg M, Chaushu G, Mazot Z, et al. Radiological findings of the post-sinus lift maxillary sinus: A computerized tomography follow-up. J Periodontol. 1999;70:1564-1573.

11. Cordioli G, Mazzocco C, Schepers $E$, et al. Maxillary sinus floor augmentation using bioactive glass granules and autogenous bone with simultaneous implant placement. Clin Oral Implants Res. 2001; 12:270-278.

12. Naitoh M, Ariji E, Okumura S, et al. Can implants be correctly angulated based on surgical templates used for osseointe- grated dental implants? Clin Oral Implants Res. 2000;11:409-414.

13. Lundgren $\mathrm{S}$, Nystrom E, Nilson $\mathrm{H}$, et al. Bone grafting to the maxillary sinuses, nasal floor and anterior maxilla in the atrophic edentulous maxilla: A two-stage technique. Int J Oral Maxillofac Surg. 1997;26: 428-434.

14. Blomqvist JE, Alberius $P$, Isaksson $\mathrm{S}$. Two-stage maxillary sinus reconstruction with endosseous implants: A prospective study. Int J Oral Maxillofac Implants. 1998;13:758-766

15. Widmark G, Andersson B, Ivanoff C-J. Mandibular bone graft in the anterior maxilla for single tooth implants. Presentation of surgical method. Int J Oral Maxillofac Surg. 1997;26:106-109.

16. Todd AD, Gher ME, Quintero G, et al. Interpretation of linear and computed tomograms in the assessment of implant recipient site. J Periodontol. 1993;64:1243-1249.

17. Naitoh $M$, Kawamata $A$, lida $H$, et al. Cross-sectional imaging of the jaws for dental implant treatment: Accuracy of linear tomography using a panoramic machine in comparison with reformatted computed tomography. Int J Oral Maxillofac Implants. 2002;17:107-112.

18. Nystrom E, Legrell PE, Forssell A, et al. Combined use of bone grafts and implants in the severely resorbed maxilla: Postoperative evaluation by computed tomography. Int J Oral Maxillofac Surg. 1995;24:20-25.

Reprint requests and correspondence to:

Munetaka Naitoh, DDS, PhD

Department of Oral and Maxillofacial Radiology School of Dentistry

Aichi-Gakuin University

2-11

Suemori-Dori, Chikusa-Ku

Nagoya 464-8651, Japan

Phone: 81-527-592-165

Fax: 81-527-592-165

E-mail: mune@dpc.aichi-gakuin.ac.jp
$\operatorname{AUTOR}(\boldsymbol{E N})$ : Munetaka Naitoh, DDS, PhD*, Karl Dula, DDS, $\mathrm{PhD}^{* *}$, Yasuhiro Ito, DDS, $\mathrm{PhD}^{* * *}$, Tetsuro Toyoda, DDS, PhD\#, Kenichi Kurita, DDS, PhD\#\#, Eiichiro Ariji, DDS, PhD\#\#\#. *A.O. Professor, Abteilung für Radiologie in Kiefer- und Gesichtsraum, zahnmedizinische Fakultät, Aichi-Gakuin Universität, klinisches Zentrum für Zahnimplantierungen, zahnmedizinische Klinik, Aichi-Gakuin Universität, Gastprofessor im Forschungsbereich, Bereich der Radiologie für Kiefer und Gesicht, Abteilung für Gesichtschirurgie und Stomatologie, zahnmedizinische Fakultät, Universität von Bern. **A. O. Professor, Bereich der Radiologie für Kiefer und Gesicht, Abteilung für Gesichtschirurgie und Stomatologie, zahnmedizinische Fakultät, Universität von Bern. ***Assistenzprofessor in Teilzeit, erste Abteilung für Gesichtsund Kieferchirurgie, zahnmedizinische Fakultät, Aichi-Gakuin Universität. \#Assistenzprofessor, Abteilung für Gesundheitsforschung, Fachbereich der psychologischen und physischen Wissenschaften, Aichi-Gakuin Universität. \#\#Professor und Vorsitzender, erste Abteilung für Gesichts- und Kieferchirurgie, zahnmedizinische Fakultät, Aichi-Gakuin Universität. \#\#\#Professor und Vorsitzender, erste Abteilung für Gesichts- und Kieferchirurgie, zahnmedizinische Fakultät, Aichi-Gakuin Universität. Schriftverkehr: Munetaka Naitoh, DDS, PhD, Abteilung für Radiologie in Kiefer- und Gesichtsraum (Dept. of Oral and Maxillofacial Radiology), zahnmedizinische Fakultät (School of Dentistry), Aichi-Gakuin Universität, 2-11, Suemori-Dori, Chikusa-Ku, Nagoya 464-8651, Japan. Telefon: +81 527592165, Fax: +81 527592165.eMail: mune@dpc.aichi-gakuin.ac.jp
Postoperative tomographische Bewertung bei Transplantierungen von Verblendungsknochenmaterialien mit anschließender Implantatsetzung im vorderen Bereich des Oberkiefers

ZUSAMMENFASSUNG: Verschiedene Methoden zur Anreicherung des Kamms und Sinusanhebung wurden in schweren Fällen von resorbierten Alveolarleisten im Oberkiefer zur Bereitstellung eines für eine Implantierungsbehandlung ausreichenden Volumens. Dem Bericht zufolge wurden die Ergebnisse der Sinusanhebungen im Oberkiefer mit entweder konventioneller Tomographie oder Computertomographie zusammengestellt. $\mathrm{Au} \beta$ erdem wies das transplantierte Knochengewebe um das Implantat herum einen besonderen Resorptionsanstieg im Bereich der Implantatspitze auf. Allerdings wurde noch keine kombinierte Behandlung mit Transplantation von Verblendungsknochenmaterialien in Verbindung mit Implantatsetzung nach Durchlauf von Bildgebenden Verfahren bewertet. Daher zielt die vorliegende Studie darauf ab, Transplantierung von Verblendungsknochenmaterial nach Implantierungsbehandlung im vorderen Oberkieferbereich zu bewerten. Sieben Patienten mit einem durchschnittlichen Alter von 24 Jahren mit Implantaten in der vorderen Oberkieferregion, die entweder mit oder ohne Transplantierung von autogenem Verblendungsknochenmaterial behandelt wurden, wurden postoperativ über konventionelle tomographische Methoden untersucht. In diesen Tomogrammen wurden das Verhältnis von Knochen-Implantat-Kontakt sowie der Bereich des Knochengewebes bei Labialknochen mit Knochengewebstransplantaten gemessen. Diese Ergebnisse wurden mit den Werten bei Auslassung einer Knochengewebstransplantation. Bei den Fällen mit erfolgter Transplantierung von Knochengewebe betrug das durchschnittliche Verhältnis von Knochen-Implantat-Kontakt 63,6\%, während in den Fällen ohne Transplantierung 81,8\% ermittelt wurden. Der durchschnittliche Knochenbereich betrug $12,9 \mathrm{~mm}$ und 23,4 mm bei Patienten entweder mit oder ohne Knochengewebstransplantat. Es konnte kein wesentlicher Unterschied für Implantate mit bzw. ohne Knochentransplantate festgestellt werden. Resorbierter Labialknochen in der Oberkieferregion lag sowohl mit als auch ohne Transplantation von Verblendungsknochengewebe vor.

SCHLÜSSELWÖRTER: Zahnimplantat, Verblendungsknochentransplantat, vordere Oberkieferregion, Tomographie, postoperative Ergebnisse 
$\operatorname{AUTOR}(\boldsymbol{E S})$ : Munetaka Naitoh, DDS, PhD*, Karl Dula, DDS, PhD**; Yasuhiro Ito, DDS, $\mathrm{PhD}^{* * *}$, Tetsuro Toyoda, DDS, PhD\#, Kenichi Kurita, DDS, PhD\#\# Eiichiro Ariji, DDS, PhD\#\#\#. *Profesor Asociado, Departamento de Radiología Oral y Maxilofacial, Facultad de Odontología, Universidad Aichi-Gakuin, Clínica de Implantes Orales, Hospital Dental, Universidad Aichi-Gakuin, Investigador Profesor Visitante, Sección de Radiología Dentomaxilofacial, Departamento de Cirugía Oral y Estomatología, Facultad de Medicina Dental, Universidad de Berna. **Profesor Asociado, Sección de Radiología Dentomaxilofacial, Departamento de Cirugía Oral y Estomatología, Facultad de Medicina Dental, Universidad de Berna. ***Profesor Asistente a tiempo parcial, Primer Departamento de Cirugía Oral y Maxilofacial, Facultad de Odontología, Universidad Aichi-Gakuin. \#Profesor Asistente, Departamento de Ciencias de la Salud, Facultad de Ciencias Psicológicas y Físicas, Universidad Aichi-Gakuin. \#\#Profesor y Jefe, Primer Departamento de Cirugía Oral y Maxilofacial, Facultad de Odontología, Universidad Aichi-Gakuin. \#\#\#Profesor y Jefe, Departamento de Radiología Oral y Maxilofacial, Facultad de Odontología, Universidad AichiGakuin. Correspondencia a: Munetaka Naitoh, DDS, PhD, Dept. of Oral and Maxillofacial Radiology, School of Dentistry, Aichi-Gakuin University, 2-4 11, Suemori-Dori, Chikusa-Ku, Nagoya 464-4 8651, Japan. Teléfono: +81527 592 165, Fax: + 81527592 165. Correo electrónico:mune@dpc.aichi-gakuin.ac.jp

AUTOR(ES): Munetaka Naitoh, CirurgiãoDentista, $\mathrm{PhD}^{*}$, Karl Dula, Cirurgião-Dentista, $\mathrm{PhD}^{* *}$, Yasuhiro Ito, Cirurgião-Dentista, $\mathrm{PhD}$ ****, Tetsuro Toyoda, Cirurgião-Dentista, PhD\#, Kenichi Kurita, Cirurgião-Dentista, PhD\#\#, Eiichiro Ariji, Cirurgião-Dentista, PhD\#\#\#. *Professor Associado, Depto. de Radiologia Oral e Maxilofacial, Faculdade de Odontologia, Universidade AichiGakuin; Clínica de Implantes Orais, Hospital Odontológico, Universidade Aichi-Gakuin, Professor-Pesquisador Visitante; Seção de Radiologia Dento-maxilofacial, Depto. de Cirurgia Oral e Estomatologia, Faculdade de Medicina Dentária, Universidade de Berna. **Professor Associado, Seção de Radiologia Dento-maxilofacial, Depto. de Cirurgia Oral e Estomatologia, Faculdade de Medicina Dentária, Universidade de Berna. ***Professor Assistente em Tempo Parcial, Primeiro Depto. de Cirurgia Oral e Maxilofacial, Faculdade de Odontologia, Universidade AichiGakuin. \#Professor Assistente, Depto. de Ciências da Saúde, Faculdade de Ciências Psicológicas e Físicas, Universidade Aichi-Gakuin. \#\#Professor e Chefe, Primeiro Depto. de Cirurgia Oral e Maxilofacial, Faculdade de Odontologia, Universidade Aichi-Gakuin. \#\#Professor e Chefe, Depto. de Radiologia Oral e Maxilofacial, Faculdade de Odontologia, Universidade Aichi-Gakuin. Correspondência para: Munetaka Naitoh, DDS, PhD, Dept. of Oral and Maxillofacial Radiology, School of Dentistry, Aichi-Gakuin University, 2-11, SuemoriDori, Chikusa-Ku, Nagoya 464-8651, Japan. Telefone: +81 527592165, Fax: +81 527592165. E-mail: mune@dpc.aichi-gakuin.ac.jp
Evaluación tomográfica postoperatoria de un injerto de veneer de hueso con colocación del implante en la región anterior maxilar

ABSTRACTO: Varios procedimientos de levantamiento del seno y aumento de la cresta se realizaron en crestas alveolares severamente reabsorbidas de una maxila para proporcionar cierto volumen para el tratamiento con un implante. Se informó que el resultado de los procedimientos de levante del seno maxilar se evaluó con tomografía convencional o tomografía computada y que el hueso injertado alrededor de los implantes progresó marcadamente en la reabsorción, particularmente en la cima del implante. Sin embargo, el injerto con veneer de hueso con la colocación del implante no ha sido evaluada después del tratamiento con técnicas de imágenes. Por lo tanto, el propósito de este estudio fue evaluar el injerto con veneer de hueso después del tratamiento con implante en el maxilar anterior. Siete pacientes con una edad media de 24 años con implantes colocados en la región maxilar anterior con o sin injertos con enchapado de hueso autógeno fueron examinados postquirúrgicamente usando la tomografía convencional. En las tomografías, la relación del contacto del hueso al implante y el área del hueso se midieron en los huesos labiales con injertos de hueso, y se compararon con los valores sin los injertos de hueso. En casos con injertos de hueso, la relación promedio del contacto de hueso al implante fue un $63,6 \%$, mientras que un $81,8 \%$ se formaron en casos sin un injerto de hueso. La superficie promedio del hueso fue $12,9 \mathrm{~mm}^{2}$ y $23,4 \mathrm{~mm}^{2}$ en pacientes con y sin el injerto de hueso, respectivamente. No se encontró una diferencia notable entre los implantes con y sin los injertos de hueso. Se observó hueso labial reabsorbido en la región maxilar anterior con y sin un injerto con veneer de hueso.

PALABRAS CLAVES: implante dental, injerto con veneer de hueso, región maxilar anterior, tomografía, conclusiones postquirúrgicas

\section{Avaliação Tomográfica Pós-Operatória de Enxerto Ósseo com Uso de Faceta e Colo- cação de Implante na Região Maxilar Anterior}

RESUMO: Vários procedimentos de aumento do rebordo e levantamento do seio foram realizados em cristas alveolares gravemente reabsorvidas de um maxilar para fornecer algum volume para tratamento de implantes. Foi relatado que o resultado de procedimentos de levantamento do seio maxilar foi avaliado com tomografia convencional ou tomografia computadorizada, e que o osso enxertado em torno de implantes progrediram marcadamente em reabsorção particularmente no ápice do implante. Contudo, o enxerto ósseo com uso de faceta e colocação de implante não foi avaliado após o tratamento com técnicas de geração de imagens. Portanto, o propósito deste estudo foi avaliar o enxerto ósseo com uso de faceta após o tratamento de implantes maxilares anteriores. Sete pacientes com idade média de 24 anos com implantes colocados na região maxilar anterior com ou sem enxerto ósseo autógeno com uso de faceta foram examinados pósoperatoriamente usando tomografia convencional. Em tomografias, a razão de contato osso/implante e a área de osso foram medidas em ossos vestibulares com enxertos ósseos, e eles foram comparados com os valores sem enxertos ósseos. Em casos com enxerto ósseo, a razão média de contato osso/implante foi de $63,6 \%$, ao passo que $81,8 \%$ foram formados em casos sem enxerto ósseo. A área média de osso foi de 12,9 mm2 e 23,4 mm2 em pacientes com e sem enxerto ósseo, respectivamente. Nenhuma diferença significativa foi encontrada entre os implantes com e sem enxertos ósseos. O osso vestibular reabsorvido foi observado na região maxilar anterior com e sem enxerto ósseo com uso de faceta

PALAVRAS-CHAVE: implante dentário, enxerto ósseo com uso de faceta, região maxilar anterior, tomografia, laudos pós-operatórios 


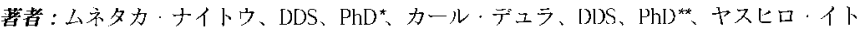

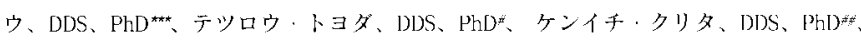
エイイチロウーアリジ、DDS、PhD亲

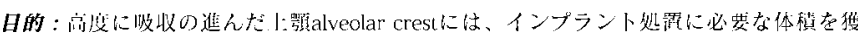

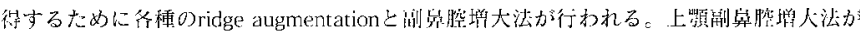

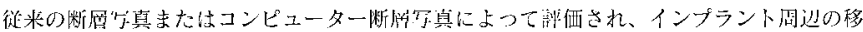

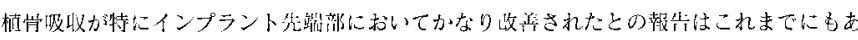

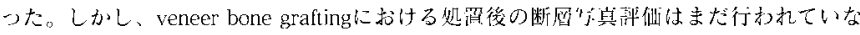

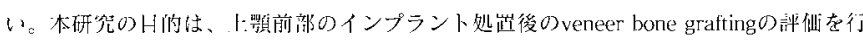
うことであつた。

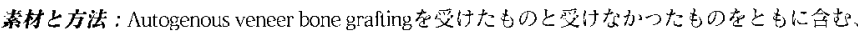

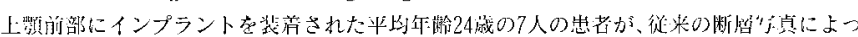

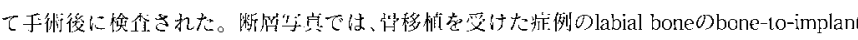

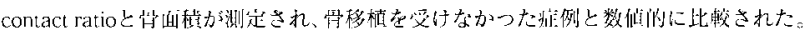

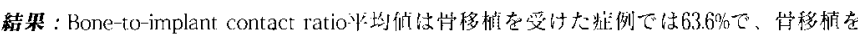

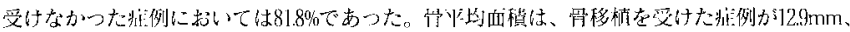

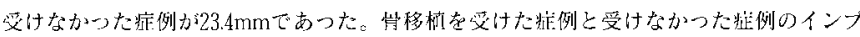
ラントには、行甞な進いが恐められながた。

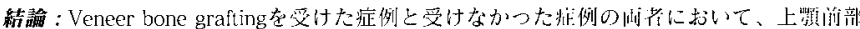
Olabial bone吸収力溜めら扎た。

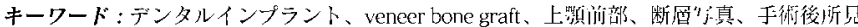

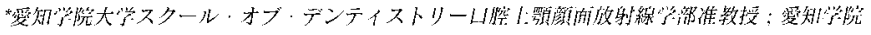

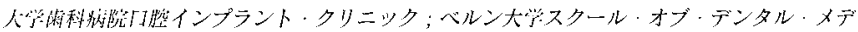

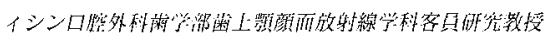

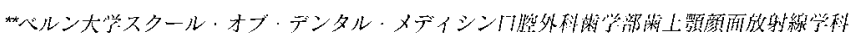

准教授

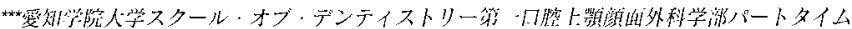

作粒授

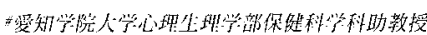

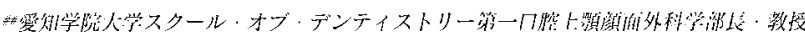

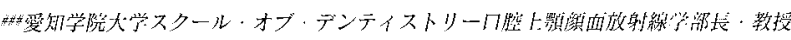

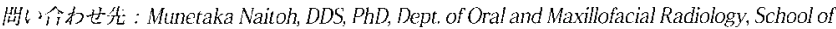
Dentistry, Aichi-Gakuin University, 2-11, Suemori-Dori, Chikusa-Ku, Nagoya 464-8651, Japan

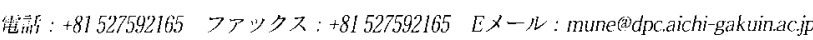

